DOI : $10.14746 /$ rie.2017.11.34

\title{
Ireneusz Kraś (red.), Zarzq̨dzanie gospodarcze Unii Europejskiej w drugiej dekadzie XXI w., Difin, Warszawa 2016, ss. 239
}

Integracja gospodarcza UE, cel przyświecający również Wspólnotom Europejskim, na każdym etapie swojego rozwoju przechodziła - mniejsze lub większe - problemy. Od ich rozwiązywania zależała jej dalsza przyszłość i docelowy kształt rozwiązań systemowych tego obszaru. Pokonywanie kolejnych stadiów, począwszy od strefy wolnego handlu, na budowie unii gospodarczo-walutowej kończąc, ujawniało swoiste dylematy, tak co do celu, jak i końcowego efektu w postaci realnych jej korzyści, jednocześnie wpisując się w polityczne uwarunkowania dążeń do zacieśnienia współpracy wewnątrz UE.

Oparta na modelu międzyrządowym, choć posiadająca elementy supranarodowe, gospodarcza integracja wspólnoty europejskiej swą uwagę kierowała zawsze na stabilność gospodarczowalutową i wzrost, rozumiany jako poszerzanie strefy dobrobytu. Warunkiem powodzenia tej inicjatywy było zintegrowanie celów polityki gospodarczej poszczególnych państw członkowskich z celami europejskimi. Osiaganie kompromisów w zakresie integracji gospodarczej lub unii walutowej nastręczało jednak periodycznie trudności, skutkując przyjęciem rozdzielnego modelu już na starcie - wspólnotowości dla rozwiązań z zakresu polityki pieniężnej oraz decentralizacji w zakresie polityk gospodarczych. Zachwiania rozwoju w tym obszarze stanowią zatem naturalną konsekwencję przyjętych rozwiązań i charakteru integracji europejskiej.

W wyjątkowych momentach jednak, gdy dochodzi do turbulencji w skali międzynarodowej, ujawniają się na dużą skalę deficyty i konstrukcyjne błędy, inicjujące na nowo dyskusje dotyczącą zasad i kształtu kluczowych aspektów. Światowy kryzys finansowy i, w jego następstwie, kryzys w Unii Europejskiej, jest takim momentem, bowiem spowodował ujawnienie strukturalno-systemowych braków UE w dziedzinie polityki gospodarczo-finansowej. Zauważalne stało się nieskoordynowanie jej w poszczególnych państwach członkowskich, szczególnie w zakresie polityki fiskalnej oraz nadzoru nad sektorem finansowym. W połączeniu z brakiem ładu instytucjonalnego w obszarze wspólnej waluty, nie tylko ukazał słabość zarządzania na poziomie UE, ale zagroził trwałości całego projektu, nie wykluczając rozpadu strefy euro lub zachwiania spójnością całej UE w sposób zasadniczy.

Każdorazowo jednak kryzys stanowi punkt zwrotny i wyzwanie, tak w zakresie krótko - jak i długofalowych rozwiązań, wymuszając zastanowienie nad kierunkami naprawy. Dzisiejsza sytuacja Unii Europejskiej skłania do refleksji na temat ewentualnej rekonstrukcji jej modelu funkcjonowania, również w zakresie zarządzania ekonomicznego. Wymuszone kryzysem reformy mechanizmów i regulacji, związanych z zarządzaniem gospodarczym, nie zmieniły zasadniczego modelu integracji w tym zakresie, pozostawiając go nadal w gestii państw członkowskich. Czy zatem reakcja wspólnoty na kryzys jest adekwatna do potrzeb Unii Europejskiej w drugiej dekadzie XXI wieku? Czy dotychczasowe rozwiązania instytucjonalne w zakresie funkcjonowania strefy euro, zarządzania finansami publicznymi, konkurencyjności UE, czy polityki makroostrożnościowej są wystarczające do przywrócenia stabilności unii gospodarczej? Spośród licznych publikacji, wpisujących się w tą problematykę, na szczególną uwagę zasługuje praca Ireneusza Krasia pt. „Zarządzanie gospodarcze Unii Europejskiej w drugiej dekadzie XXI wieku", wydanej przez Wydawnictwo Difin w Warszawie. Kompleksowo analizuje unijny system gospodarczy, zasady realizacji integracji walutowej i działania, w tym zmiany instytucjonalne, wprowadzane w UE na przestrzeni ostatnich lat, próbując objaśnić racjonalność i korzyści, wspólnego dla państw o zróżnicowanym stopniu rozwoju gospodarczego, odmiennych rozwiązaniach instytucjonalnych oraz odmienności cykli koniunkturalnych, projektu. 
Licząca 241 stron publikacja składa się z 10 rozdziałów, w których zarówno teoretycy - pracownicy naukowi, reprezentujący różne ośrodki badawcze w Polsce, jak i praktycy - pracownicy instytucji finansowych, Narodowego Banku Polskiego i Komisji Nadzoru Finansowego, omawianej dziedziny zmierzyli się z oceną skutków aktualnych problemów UE. Dobór autorów stanowi niewątpliwy atut publikacji, umożliwiający szerokie spektrum podejść i interpretacji zagadnienia, a także ciekawe i oryginalne wnioski.

Jasno zarysowany cel główny recenzowanej publikacji - analiza rozwiązań instytucjonalnych i działań, jakie zostały podjęte w związku z problemami zarządzania gospodarczego UE podczas ostatniego kryzysu, został dookreślony szeregiem celów szczegółowych, w postaci rozważań na temat fiskalnego wymiaru zarządzania finansami publicznymi w Unii Europejskiej i w Polsce; konkurencyjności UE i wpływu na nią zmian w zarządzaniu ekonomicznym; perspektyw funkcjonowania strefy euro i przyczyn jej kryzysu; rozwiązań instytucjonalnych w zakresie realizacji polityki makroostrożnościowej w UE i państwach członkowskich; zmian potencjału gospodarczego UE w wyniku kryzysu; interakcji zachodzących w obszarze regulacji finansowych między UE a instytucjami międzynarodowymi; ważniejszych problemów rozwoju regionalnego UE; wpływu systemu gwarancji depozytów na stabilność systemu finansowego UE; zarządzania finansowego UE z punktu widzenia Niemiec.

Rozdział pierwszy Problem efektywnego zarzadzania finansami publicznymi. Wymiar fiskalny $w$ Unii Europejskiej $i$ w Polsce, analizie poddaje nierównoważenie sfery finansów publicznych, zwracając uwagę na trudności prowadzenia racjonalnej polityki fiskalnej i prawidłowego fiskalnego zarządzania gospodarczego na poziomie państw członkowskich i poziomie ponadnarodowym. Autor kreśli skalę nadużyć podatkowych i przykłady uchylania się od opodatkowania, równocześnie pokazując w jaki sposób wzmocnić finanse publiczne, przeciwdziałając ich drenażowi i poprawiając przestrzeganie przepisów podatkowych. Ciekawym dopełnieniem treści jest dywagacja na temat potrzeby nowoczesnego „europejskiego patriotyzmu gospodarczego" w sferze podatkowej.

Drugi rozdział Ryzyko obniżania konkurencyjności Unii Europejskiej a economic governance zwraca uwagę na aspekty konkurencyjności UE i jej poszczególnych członków względem Stanów Zjednoczonych i regionu Azji Wschodniej. Długofalowe rozwiązania problemu zadłużenia poszczególnych krajów wymagają wzrostu gospodarczego, warunkowanego utrzymaniem lub podwyższeniem konkurencyjności europejskiej gospodarki, a w tym względzie Unia Europejska notuje spadki. Nawet wiodące kraje UE z trudem utrzymują miejsca w czołówce rankingów globalnej konkurencyjności. Autorzy w tym kontekście zwracają uwagę na konieczność podjęcia próby silniejszego skoordynowania polityk gospodarczych, poprzez realizację postulatu utworzenia systemu organów stymulujących konkurencyjność.

Rozważania na temat instytucjonalnych rozwiązań w polityce makroostrożnościowej UE, uwzględniających pozycję banku centralnego, to problematyka rozdziału trzeciego. Autor, diagnozując wystąpienie luki instytucjonalnej w zakresie polityki pieniężnej i mikroostrożnościowej, weryfikacji poddał hipotezę odnośnie wiodącej roli banku centralnego w ewentualnych rozwiązaniach instytucjonalnych dotyczących realizacji polityki makroostrożnościowej. $\mathrm{Na}$ jej potwierdzenie przytacza argumenty, przemawiające za tym rozwiązaniem - prewencyjny charakter tego rodzaju polityki, doświadczenia banków centralnych w zakresie działalności na rzecz stabilności finansowej, ich niezależność instytucjonalną oraz celowość działania, ukierunkowaną na stabilność cen. Istotnie, usankcjonowaniem kluczowej roli banku centralnego w polityce makroostrożnościowej są rozwiązania organizacyjne Europejskiej Rady ds. Ryzyka Systemowego, struktury funkcjonującej w ramach Europejskiego Systemu Nadzoru Finansowego, odpowiedzialnej za prowadzenie polityki makroostrożnościowej w odniesieniu do UE jako całości, a która skupia przedstawicieli banków centralnych państw członkowskich, z prezesem Europejskiego Banku Centralnego na czele.

Trzy kolejne rozdziały podejmują problematykę funkcjonowania strefy euro. Czwarty - jest analizą jej obecnego stanu, ale również perspektywy przyszłości, piąty - przyczyn kryzysu 
w strefie euro w ujęciu teoretycznym. Dla czytelnika przejrzystsza byłaby wprawdzie zamiana kolejności obu artykułów, niemniej podejmują one aktualną i istotną tematykę w kontekście obecnych problemów południowych krajów-członków strefy euro, z niejednoznacznym dalszym ciagiem funkcjonowania wspólnotowego obszaru walutowego. Bo czy wprowadzone ostatnio zmiany instytucjonalne - budowa unii bankowej, nadzór fiskalny i zwiększony stopień koordynacji polityk fiskalnych, to wystarczające remedium na sytuacje kryzysowe, w warunkach braku kluczowych procedur, w tym postępowania w sytuacji niewypłacalności krajów, czy mechanizmu ubezpieczeń fiskalnych na wypadek wystapienia szoków asymetrycznych? Odpowiedzi na pytanie o zasadność przebudowy strefy euro i ,jakość” istniejących instrumentów udziela natomiast rozdział szósty, konkludując, że z kryzysu wzmocnione wychodzą Niemcy, podczas gdy inne kraje muszą dopiero opracować nowe metody zarządzania własnymi finansami.

Interakcje zachodzące w obszarze regulacji finansowej między UE a instytucjami międzynarodowymi są tematem rozważań kolejnego Autora, analizującego wpływ tych ostatnich na tworzenie architektury finansowej w UE. Tekst w swojej treści zwraca uwagę, że kreowanie globalnie obowiązujących norm postępowania w zakresie zarządzania finansowego jest specyficzne, bo przybierające często formę miękkiego prawa, dobrowolnie przyjmowanych przez państwa członkowskie zobowiązań, ustalanych niejednokrotnie na forum instytucji niebędących organizacjami międzynarodowymi (jak np. G-20).

Rozdział Główne problemy rozwoju regionalnego w UE a cele $i$ narzędzia finansowe polityki regionalnej wskazuje, że obecna realizacja polityki regionalnej UE oparta jest na koncepcji wzrostu endogenicznego, zorientowanego na maksymalne wykorzystanie własnych zasobów, według innowacyjnych metod zarządzania gospodarczego, w odróżnieniu od początków jej rozwoju, kiedy podstawę stanowiła teoria wzrostu egzogenicznego, połączonego z podejściem kompensacyjnym i/lub redystrybucyjnym Autorka, ukazując ewolucję problemów polityki regionalnej, zestawia ją z analizą aktualnych celów, kierunków i priorytetów oraz instrumentów - finansowych, organizacyjnych i prawnych - niezbędnych do ich eliminowania.

Dziewiąty rozdział porusza kwestie systemu gwarancji depozytów w sieci bezpieczeństwa finansowego, jego rolę i wpływ na wzrost stabilności finansowej. Stanowi on istotny element sieci bezpieczeństwa finansowego, która po kryzysie przechodzi poważną reformę w postaci wspierania szeroko pojętej stabilności finansowej, a która to, mimo utrzymania tego samego celu, zmienia pierwotną koncepcję zasadniczo.

Opracowanie kończy temat Niemiecka wizja rozwoju strefy euro. Autor stawia tezę, że stanowisko Niemiec - wyjątkowe na tle innych państw UE - w kwestii architektury instytucjonalnej strefy euro oraz interpretacje kryzysu wspólnej waluty kształtowane jest przez ściśle niemieckie tradycje historyczne i ekonomiczne. Charakteryzuje zatem, odgrywający kluczowe znaczenie w niemieckiej myśli ekonomicznej, nurt zwany ordoliberalizmem, ukazując przykłady wpływu tej idei na kształt reżimu wspólnej waluty w Europie (m.in. konstrukcja i mandat Europejskiego Banku Centralnego, podkreślanie znaczenia reguł prawnych i konieczność ich przestrzegania: kryteria konwergencji z Maastricht, Pakt Stabilności i Wzrostu oraz Pakt Fiskalny). Stanowisko Niemiec wobec strefy euro krytykowane jest przez pozostałe państwa europejskie, jako nieuwzględniające chociażby nieredukowalnego, politycznego wymiaru problemów wspólnej waluty. Bo, zdaniem wielu, problemy strefy euro wynikają z braku ,zakorzenienia” wspólnej waluty w rzeczywistych ponadnarodowych, europejskich instytucjach finansowych, fiskalnych i rządowych.

Publikację zamyka Zakończenie redaktora naukowego, w którym prezentuje wyciągnięte wnioski, sugerując jednocześnie konieczność uzupełnienia opracowania o dodatkowe cele szczegółowe, skromnie zaznaczając niewyczerpanie celu głównego w stopniu całkowitym, skądinąd chyba nie do końca możliwe ze względu na ambitność postawionego sobie celu.

Zakres podejmowanych zagadnień wskazuje na profesjonalizm autorów poszczególnych rozdziałów, a niewątpliwym atutem publikacji jest aktualność zaprezentowanego tematu. Za- 
sługuje ona na uwagę ze strony przedstawicieli różnych środowisk, ale przede wszystkim tych, którzy chcą poszerzyć swoją wiedzę z zakresu polityk ekonomicznych UE. Jej wieloaspektowy charakter umożliwia zrozumienie istoty, mechanizmów oraz przyczyn występowania sytuacji problemowych w zarządzaniu gospodarczym UE, jednocześnie wskazując perspektywę na przyszłość w kontekście rozwiązywania jego deficytów. Poza cennym źródłem informacji publikacja stanowi przyczynek do dalszej dyskusji dotyczącej zarządzania gospodarczego i finansowego UE, uzupełniając dotychczasowy stan literatury.

MAŁGORZATA SOJA

Akademia im. Jana Długosza w Częstochowie 